\title{
About new aspects of the development of the market of mini apartments in Ukraine
}

\author{
Sergiy Kobzan*, and Sergiy Nesterenko \\ National University of Urban Economy in Kharkiv, 17, Marshal Bazhanov Street, Kharkiv, 61002, Ukraine
}

\begin{abstract}
The article discusses the issues of a new segment of the real estate market in urban development projects. The analysis of the world market of mini apartments is made. The questions of residence of various social groups in mini apartments are raised. The classification of mini apartments has been developed. The factors significantly affecting the cost of a mini apartment are investigated. The calculation of the analysis of benefits and costs for a mini apartment. Conclusions are drawn about the mini-apartment market in urban development. The research of mini-apartments' market reflects changes in the development of the whole urban infrastructure. The market of mini-apartments influences on the real estate region's market. The distinctive characteristics of mini-apartments in different regions are based on their classification. The mini-apartments' market in different regions is analyzed. The authors constructed GIS-map. GIS analysis shows the dependence of the cost of mini apartments from the region of Ukraine. Calculation of the profitability of mini apartments was carried out using the method of market extraction (market sampling). Using the method of market extraction (market sampling), the income from mini apartments was calculated. Cost benefit analysis shows the aspects of the mini apartments' market for the urban development.
\end{abstract}

\section{Introduction}

The first time mini-apartments - studios appeared as a budget housing was in the 1920s in the US. They were in a high demand among the poorest groups of the population. The accommodation had open space and separate bathroom. It became convenient for the students, single and creative people. It was an excellent solution to the housing problem $[1,2]$. At the present time studio apartments have become popular all over the world.

A studio apartment, also known as a studio flat is a small apartment which combines living room, bedroom, and kitchen into one room.

In Italy such objects are called "monolocale". In Japan such objects which are studio apartments known are called the one room mansion. In United States (New York) is the "L-shaped" or "alcove" studio. In Canada "bachelor" apartment. In Czech Republic - Garsoniéra. In Poland studio apartments are called "Kawalerka". In United Kingdom such objects are called studio flats [15].

We have done an analysis of the value of real estate in different countries of Europe. We took the statistics of the average cost of $1 \mathrm{~m}^{2}$ apartments with an area of about 120 $\mathrm{m}^{2}$ located in major cities of Europe as of August 2019. Dynamic of residential property can be seen on Figure 1 .

The residential property market in Europe shows signs of recovery, one of the main characteristics is the price increase. After the financial crisis, many European real estate markets became more active and the prices started to rise.

\footnotetext{
* Corresponding author: s.kobzan@gmail.com
}

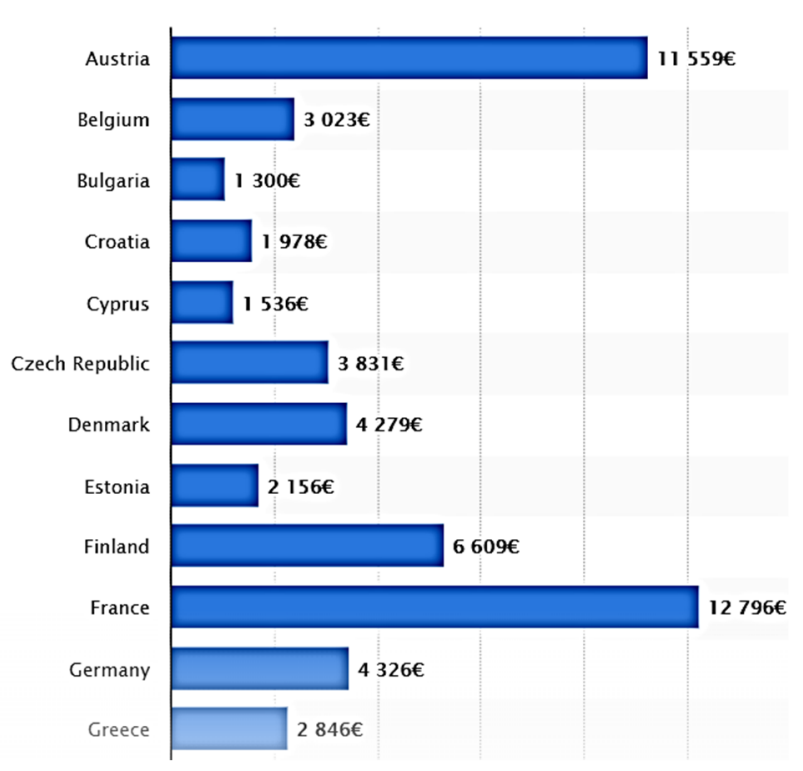

Fig. 1. Average price of residential property in EU-12 according to the statistics [14].

Average prices of 120 square meter apartments located in the most important cities of EU-12 countries were highest in the United Kingdom, France and Austria as of August 2019. These cities could either be the administrative capital, the financial capital and the center of the rental market.

Newly built and pre-sale property prices were not included. An apartment located in the United Kingdom most important city would therefore cost approximately 
21,179 euros per square meter. The source does not specify the cities and states that the numbers provided in this ranking have been taken from several national publications, for example from national statistical bureaus. This is because no European level body exists that tracks house prices. As of July 2018, the average price for a house in the UK was 231,163 British pounds.

With this development of the real estate market, it is necessary to analyze the activity of the mini-apartment market. Studies have shown that the cost per square meter of a standard apartment is approximately equal to the cost per square meter in a mini apartment. The rent for a mini apartment is higher.

In Ukraine "gostinka" is a mini apartment in an apartment building with its own mini-bathroom and minikitchen. This is a small room without walls or partitions, mostly adapted for 1-2 people and a total area of $25 \mathrm{~m}^{2}$. In fact, this is a new kind of social housing.

\section{The development of the market of mini apartments in Ukraine}

The development of the market of mini apartments can be regarded as a new social phenomenon. Many social groups can afford them to buy a mini apartment.

The real estate market is at a difficult stage now [1518]. The economic crisis had a strong impact on stakeholders $[4,16]$ :

1. Developers are forced to reduce the cost of housing.

2. Customers have less money to buy.

The reconstruction of the old houses, factories, unfinished buildings began. In Kharkiv, one of the major cities in Ukraine, all these buildings were reconstructed as a special house with mini apartments. This direction is developing rapidly today. Houses with mini apartments exist practically in all parts of the city. In urban planning, it is necessary to consider the development of this market segment and its impact on various social groups of the population [3, 15, 20]. For example, developers in Kharkiv are building the following residential complexes with mini apartments: "Vorob yovi Gori", "Alekseevskiy Akvarali", "Bestuzhevsky Sadi", "Uytniy Dvorik", "Eloviy Dvor", "Caramel" and other medium and small projects.

There are more than 30 kinds of such constructions in Kharkiv now.

The market of mini apartments in Ukraine is a very interesting social phenomenon that has not been explored yet. The market of mini apartments influences on the urban development, but it has high uncertainty in further development. Therefore, the development of the mini apartment market poses many challenges for urban development in the future.

Mini apartments are now actively purchased by the following social groups of people:

1. Lonely, independent young people.

2. Young families.

3. Pensioners.

4. Creative people, usually they use it as a separate workspace (workshops, photo studios, small offices, etc.). 5. Investors for rent and income generation.
The activity in Ukrainian real estate market in such segment as mini apartments has increased currently. The results of the conducted studies show that the interval of cost is $1 \mathrm{~m}^{2}$ for such objects is very large and ranges from $\$ 300$ to $\$ 1000$. This is 2 times lower than the average market prices for standard apartments.

Let's analyze the interaction of the primary and secondary markets of mini apartments. Residential complexes with mini apartments can be characterized as: - new - building and in a new location;

- reconstructed from the former hostels - internal reconstruction;

- reconstructed from commercial buildings, for example, former buildings of the plant management (internal reconstruction);

- reconstruction with superstructure of floors;

- reconstruction with the addition of premises (as a rule, large areas).

Stakeholders are interested in mini apartments in reconstructed houses. In these houses, the cost of mini apartments is much lower. And mini apartments are sold at the lowest market value.

We propose a classification of mini apartments:

By location:

1. Remote zones - factory buildings.

2. Remote zones - residential development.

3. Middle areas in non-residential buildings.

4. Middle areas in residential development.

5. Zones close to the center and center in nonresidential buildings.

6. Zones close to the center and the center in the residential building.

By living area:

1. Large rooms over $20 \mathrm{~m}^{2}$.

2. The average size of 10 to $20 \mathrm{~m}^{2}$.

3. Smaller than $10 \mathrm{~m}^{2}$.

By the presence or absence of a bathroom and a mini kitchen:

1. Own bathroom, mini kitchen is separated from the bedroom.

2. Own bathroom, mini kitchen is in the room (studio).

3. Own bathroom, no mini kitchen.

4. A common bathroom, a common mini kitchen.

The Kyiv International Institute of Sociology and the Institute for Economic Research and Political Consultations of Ukraine conducted research and determined the investment attractiveness rating of the regions of Ukraine [7-9]. Rating of investment attractiveness and average cost of $1 \mathrm{~m}^{2}$ of mini apartments in Table 1.

We processed and analyzed the data in Table 1 and built a GIS map. The GIS map shows the distribution of the cost of $1 \mathrm{~m}^{2}$ mini apartments in large Ukrainian cities on Figure 2.

Based on GIS analysis, we can conclude that the cost of $1 \mathrm{~m}^{2}$ of mini apartments depends on the investment attractiveness of the regional center in Ukraine [9, 13]. This information confirms the presence of a multifactor component and the investor's interest depends not only on the buyer's demand for the acquisition of real estate in the city [20-22]. It is necessary to pay attention to the stability 
and a rating indicator on investment rating of a city [1012], [16].

We classified mini apartments according to factors that can significantly change the market value [21, 22]. These factors can increase or decrease the market value of real estate [2]. Such a parameter as the ratio of total and living space can also significantly change the market value for a mini apartment.

As a result of the research, the author suggests factors affecting the market value for a mini apartment.

1. Location (distance from transport and public infrastructure).

\section{Floor.}

3. Material of walls and ceilings.

4. The general plan of a mini apartment.

5. Design features of a mini apartment (shape and size of the room).

6 . The availability and size of the toilet.

7. The availability and size of the kitchen.

8 . The availability of a balcony.

9. General condition of entrances, common corridors and adjacent territory.

10. The availability of autonomous heating and the total cost of utility payments.

11. The number of rooms and neighbors on the floor and in the entrance.

12. The general level of the social groups, which is showing their standard of living.
Table 1: Investment rating and average cost of $1 \mathrm{~m}^{2}$ of mini apartments for large cities in Ukraine.

\begin{tabular}{|c|c|c|}
\hline City & $\begin{array}{c}\text { Cost of mini apartment } \\
\text { for } 1 \mathrm{~m}^{2}, \$\end{array}$ & $\begin{array}{c}\text { Investment } \\
\text { rating, \$ }\end{array}$ \\
\hline Lviv & 946 & 3,662 \\
\hline $\begin{array}{l}\text { Ivano- } \\
\text { Frankivsk }\end{array}$ & 401 & 3,381 \\
\hline Odessa & 916 & 3,337 \\
\hline Vinnitsa & 446 & 3,266 \\
\hline Kyiv & 1070 & 3,246 \\
\hline Dnipro & 591 & 3,243 \\
\hline Lutsk & 448 & 3,225 \\
\hline Kharkiv & 696 & 3,211 \\
\hline Chernigov & - & 3,195 \\
\hline Zhitomir & 453 & 3,168 \\
\hline Ternopil & - & 3,102 \\
\hline Zaporozhye & 443 & 3,099 \\
\hline Rovno & - & 3,072 \\
\hline Sumy & 378 & 3,063 \\
\hline Mykolaiv & - & 3,040 \\
\hline Cherkassy & - & 2,996 \\
\hline Khmelnytskyi & 416 & 2,948 \\
\hline Poltava & 457 & 2,935 \\
\hline Kirovohrad & 400 & 2,935 \\
\hline Uzhhorod & - & 2,914 \\
\hline Kherson & - & 2,891 \\
\hline Chernivtsi & - & 2,859 \\
\hline
\end{tabular}

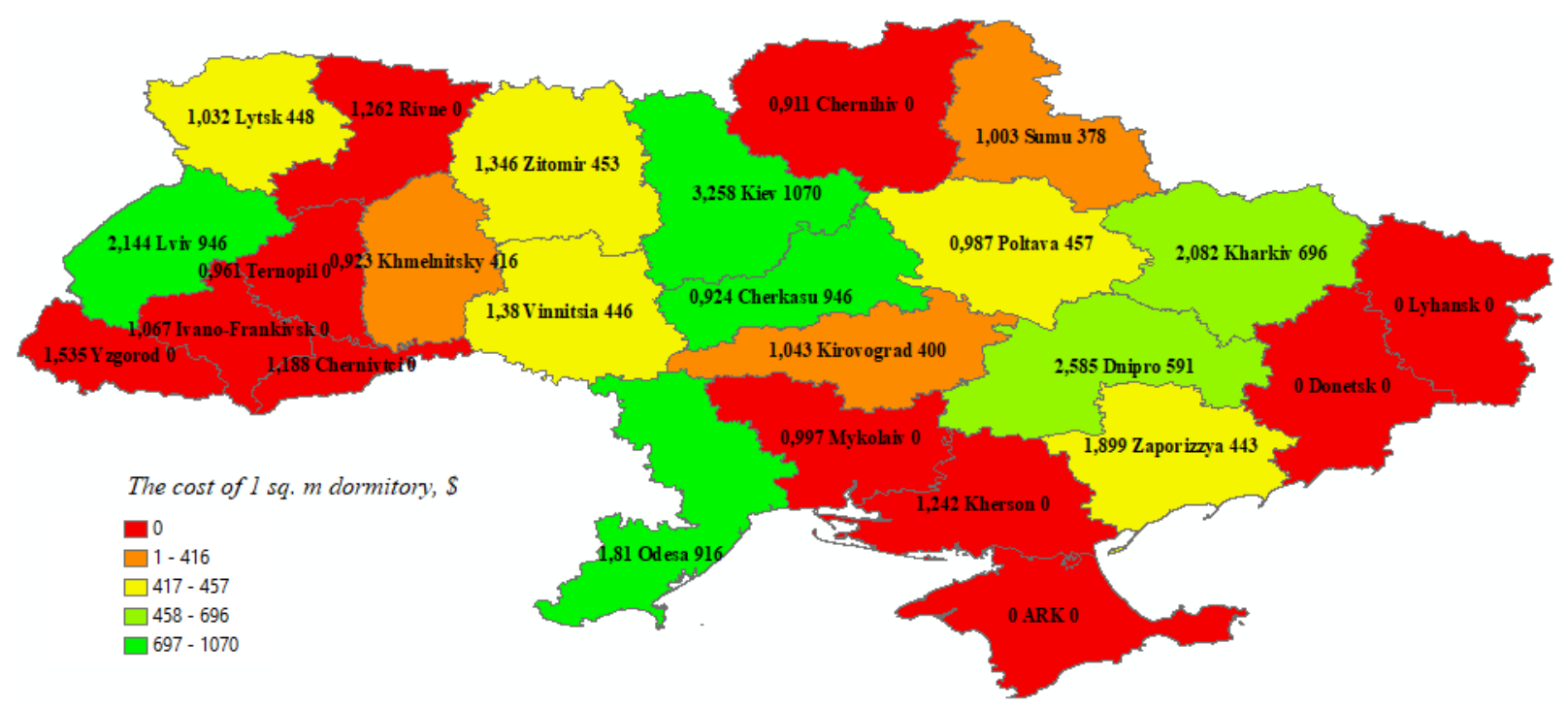

Fig. 2. GIS map of the distribution of the cost of $1 \mathrm{~m}^{2}$ of mini apartments in Ukrainian cities.

In Ukraine, the market of mini apartments (Gostinka) has formed and developed because of the unstable economic situation, devaluation of UAH and a decrease in the incomes of the population. Today, renting apartments is expensive, so mini apartments are the best option for affordable housing. Many people buy mini apartments as a temporary housing. This segment of real estate has a high profitability for investors. The cost of 1 $\mathrm{m}^{2}$ of mini apartments depends on investment rating of large cities in Ukraine.

\section{The market research in Kyiv and Kharkiv}

In many large cities of Ukraine, especially in Kyiv and Kharkiv, the number of mini apartments, being under construction is growing. The analysis showed the market that such apartments are in demand among stakeholders today $[17,18]$.

Factors of increasing the demand for mini apartments:

- an unstable economic situation;

- reduction of money supply in the population; 
- distrust of the banking sector;

- large bills for the use of real estate;

- high payments for real estate with a large area;

- increased functionality;

- comfortable for 1-2 people.

In Kyiv, there are about 10 new housing complexes with mini apartments. For example, there are such housing complexes as: "Smart House", "Comfort Town", "Yaskravy", "At Levadnaya", "Vlasna Apartment", "Zhuliany", "Yeniseiskaya Usadba", "Henesi House", "New England".

The minimum price for a mini-apartment in Kharkiv varies from 6,000 \$, in Kyiv - from 10,000 \$.

The market value of a mini apartment grows from the beginning to the finishing of the building at 2-4 thousand dollars more. This is about $20-30 \%$ of the market value [5].

In Kharkiv, mini apartments in new houses are sold without renovation. In Kyiv - with full renovation, often with equipment. A feature of the Kharkiv market is that there are two-level mini-apartments (smart-apartments). In Kyiv, there are none. Studies of the rental market show that there are 78 mini apartments in Kharkiv for rent. In Kyiv 32 mini apartments exposed for a long period of time. A mini apartment rent in Kyiv costs 3,500-8,500 UAH per month, in Kharkiv - 2,000 - 5,000 UAH per month. Daily rent of mini apartments in Kharkiv is more than in Kyiv. Nowadays there are 16 daily rentals in Kharkiv, while in Kyiv there are only 5 [18].

Thus, we can conclude that the market of mini apartments in Kharkiv is more developed than in Kyiv. In Kharkiv, people buy more mini apartments units for the purpose of further renting it out than in Kyiv. The entire market of mini apartments (gostinka) in Ukraine is actively developing.

\section{The calculation of income received from mini apartments. Cost benefit analysis}

Mini apartment is the most profitable object for investment. This is the best segment of real estate with minimal investment and maximum income on the invested capital.

We will analyze the benefits and value [17] for a mini apartment. We calculate the net operating income for mini apartment in a residential area of Kharkiv in Table 2.

Table 2. Information about the mini apartment for rent.

\begin{tabular}{|c|c|c|}
\hline Apartment & Characteristics & $\begin{array}{c}\text { Income } \\
\text { per } \\
\text { month }\end{array}$ \\
\hline $\begin{array}{c}\text { Mini } \\
\text { apartment }\end{array}$ & $\begin{array}{c}\text { "Rent an excellent gostinka, 4/5, a } \\
\text { in. kitchen, area 20 m², 7800 \$" }\end{array}$ & $\begin{array}{c}4000 \\
\text { UAH / } \\
\text { month }\end{array}$ \\
\hline
\end{tabular}

An example of calculating the income from a mini apartment in Table 3.

We apply the method of market extraction (market sampling) [23], to cost benefit analysis. Using this method, we calculate the capitalization rate $(R)$.
Table 3. An example of calculating the income from a mini apartment.

\begin{tabular}{|l|c|}
\hline \multicolumn{1}{|c|}{ Name } & Value, UAH \\
\hline 1. Potential gross income (PGI) & 4000 \\
\hline 2. Annual PGI & 48000 \\
\hline 3. Losses (5\% from PGI) & 2400 \\
\hline 4. Real gross income (per year) & 45600 \\
\hline 5. Operating expenses, including: & 15000 \\
\hline - communal payments & 6000 \\
\hline - maintenance & 2000 \\
\hline - payment for management company services & 4800 \\
\hline - advertising & 700 \\
\hline - accounting services & 1000 \\
\hline - real estate taxes (land tax, property tax) & 500 \\
\hline 6. Net operating income (NOI) & 30600 \\
\hline
\end{tabular}

The calculation results are tabulated and are given in Table 4.

Table 4. Calculation of the capitalization rate and payback time.

\begin{tabular}{|c|c|c|c|c|}
\hline Object & $\begin{array}{c}\text { V, } \\
\text { UAH }\end{array}$ & $\begin{array}{c}\text { NOI, } \\
\text { UAH }\end{array}$ & $\mathbf{R = N O I / V x 1 0 0 \%}$ & $\begin{array}{c}\text { Payback time } \\
(\mathbf{1} / \mathbf{R}), \text { year }\end{array}$ \\
\hline 1 & 210600 & 28700 & 1,4 & 7,1 \\
\hline 2 & 300000 & 50000 & 1,7 & 5,9 \\
\hline 3 & 250000 & 40000 & 1,6 & 6,25 \\
\hline 4 & 330000 & 48000 & 1,5 & 6,7 \\
\hline 5 & 275000 & 35000 & 1,3 & 7,7 \\
\hline & & & Average $R=1,5$ & \\
\hline
\end{tabular}

The capitalization rate is calculated as the ratio of net operating income (NOI) to market value (V) and is based on market information about similar real estate properties [17].

Today it is very profitable to invest in a mini apartment and rent out. The capitalization rate (the rate of return of capital) will be $15 \%$. However, the payback period for such facilities will be from 6 years to 8 years.

\section{The prospects of urban development of the mini apartment market}

In the real estate market of Kharkiv, in the segment of mini apartments, there are many categories of such apartments [5]. The cost of mini apartment on Figure 3.

In order to sell mini apartments when the real estate market is in the low activity, owners use marketing levers to stimulate demand:

- provide payment by installments;

- make a discount for repairs;

- carry out various kinds of actions (for example, furniture as a gift).

It should be noted that some similar objects are not sold for a very long time.

The cheapest mini apartments according to 01/04/2018 are for sale in the KhTZ area - from 4,000 \$. The average offer price of one-room mini apartments with its own bathroom is $8,000 \$$, with a shared bathroom $6,000 \$$. The average range of the cost of mini apartments ranges from $3,000 \$$ to $16,000 \$[16]$.

Mini apartments in the reconstructed houses can be 
bought from $8,000 \$$ to $17,000 \$\left(400-700 \$ / \mathrm{m}^{2}\right.$ an area of $10-36 \mathrm{~m}^{2}$ ). Buying redecorated mini apartment will cost $1000 \$ / \mathrm{m}^{2}$.

Thus, we can conclude that the range of value of 1 square meter in this segment of real estate varies very much. From $300 \$$ to $700 \$$ and even reaches up to $1,000 \$ / \mathrm{m}^{2}$. The rental market for mini apartments has a range of $90-198 \$$ on Figure 4.

The market of mini apartments is the most promising for investments in the structure of city development [18].

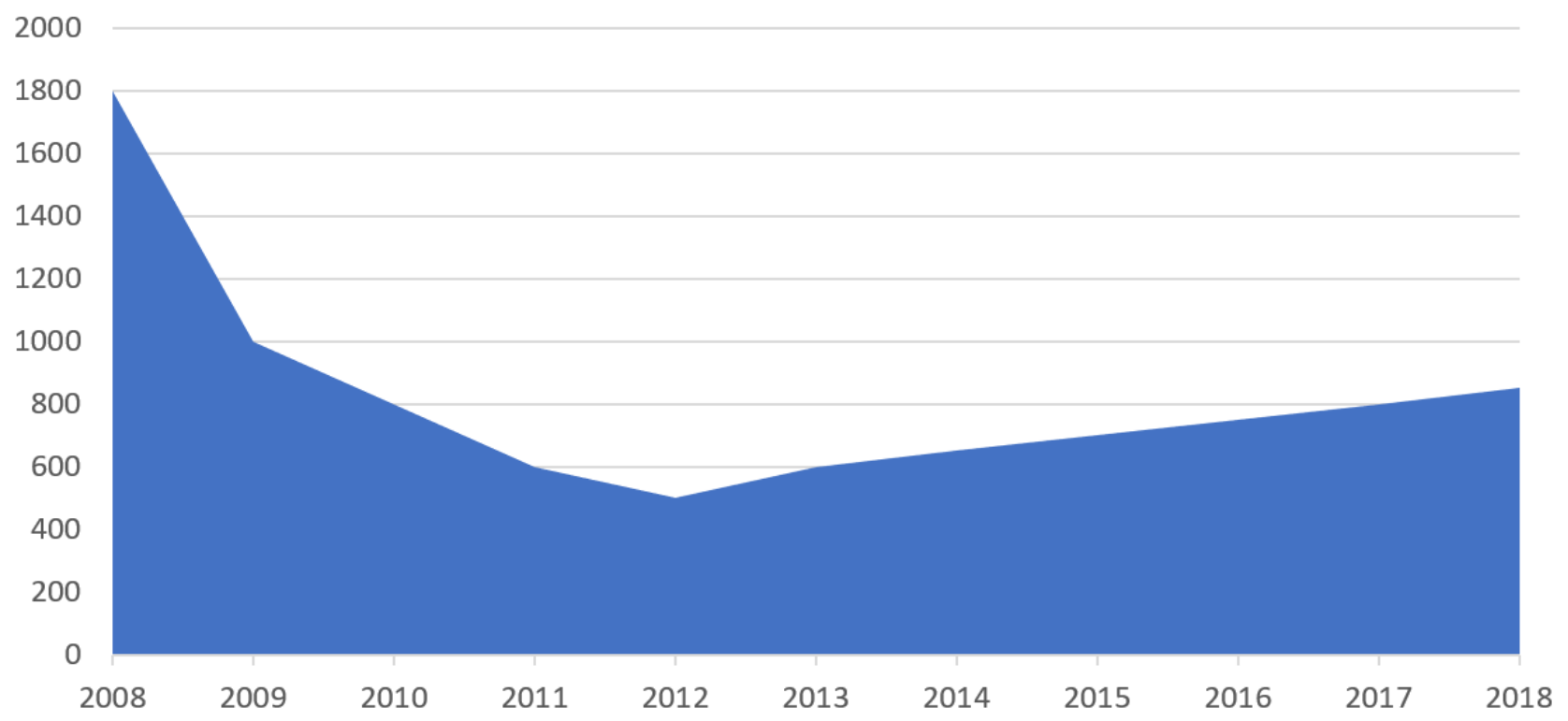

Fig. 3. The cost of mini apartments from 2008 to 2018 [17].

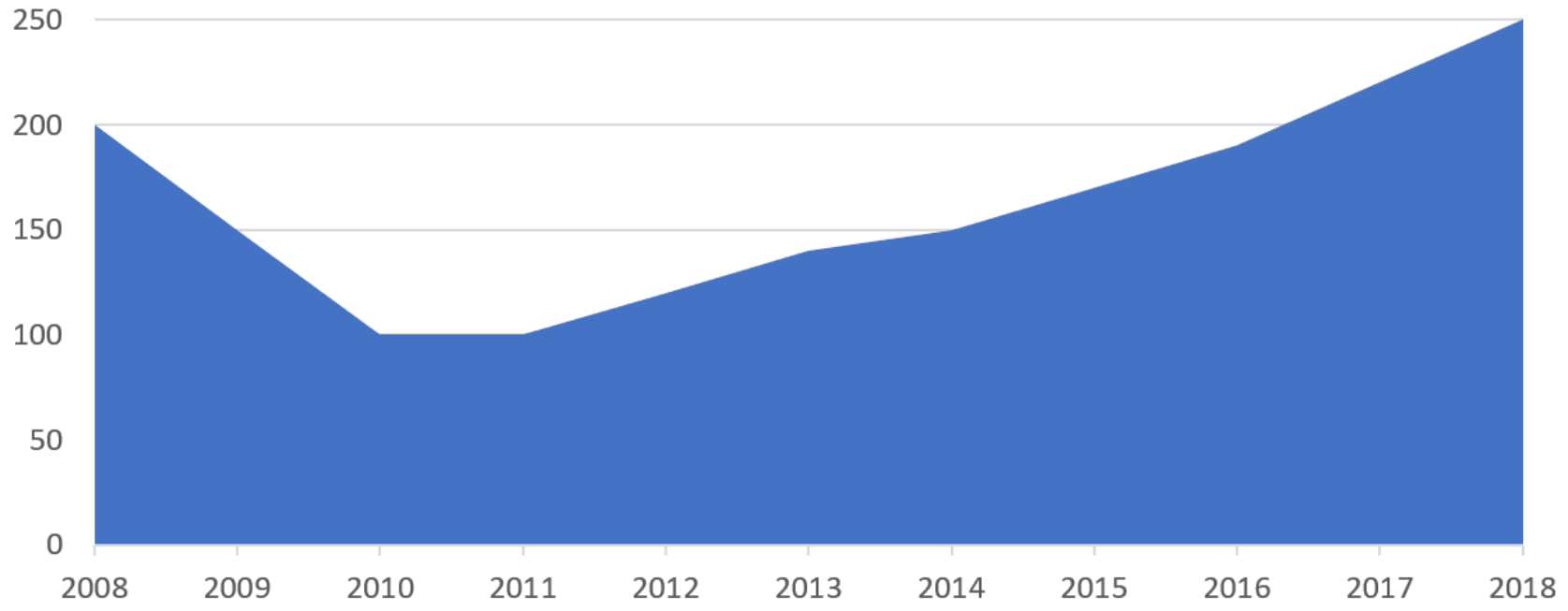

Fig. 4. The average price of renting a mini apartment in Kharkiv, [17].

\section{Conclusions}

1. The development of the mini-apartment market can be regarded as a new social phenomenon in the large cities of Ukraine. The decision on the issue of a new segment of the real estate market in urban development projects is highly relevant.

2. In Ukraine, the market of mini apartments has emerged and is developing because of the unstable economic situation, the devaluation of the hryvnia and the decrease in the incomes of the population. The cost of 1 square meter of mini apartments depends on the investment attractiveness of the regional center.

3. In Kharkiv, customers buy more mini apartments for the purpose of further rental than in Kyiv. The entire market of mini apartments in the large cities of Ukraine is actively developing.

4. The range of cost of $1 \mathrm{~m}^{2}$ in this segment of real estate varies from $300 \$$ to $1,000 \$$. The rental market for mini apartments has a range of $77-193 \$$ for a mini apartment.

5. Today, it is very beneficial to invest in a mini apartment and renting out. The capitalization rate (the rate of return of capital) will be $15 \%$. The payback period for such an object will be from 6 years to 8 years. 


\section{References}

1. V. Petrushina, M. Boytsova, Real estate operations, 3rd edn. (Factor, Kharkiv, 2010)

2. K. Peichev, Yu. Lyashenko, V. Levkov, Operations with land. 3rd edn. (Factor, Kharkiv, 2013)

3. K. Mamonov, T. Anoprienko, Analysis of the real estate market and technology of the real estate business of Kharkiv (FLP Panov, Kharkiv, 2016)

4. S. Kobzan, A. Popov, V. Ryltseva, Real Estate Market: from realtor to investor (FLP Panov, Kharkiv, 2017)

5. S. Kobzan, Formation of the real estate market: practical aspects and features of the assessment (Urinkom, Kyiv, 2019)

6. K. Vytkin, Land administration: Peculiarities of formation and modern technologies of realization, ed. by K. Mamonov (FOP Mezina, Kharkiv, 2018)

7. Rating rozvitku mist of Ukraine (2018), http: //www.ipa.net.ua. Accessed 22 Feb 2018

8. The rating of development city of Ukraine (2018), http://www.ipa.net.ua. Accessed 22 Feb 2018

9. Rating of the privatization of the Ukraine / Institute of Economic Affairs of the Council of Political Consultations: for the consolidation of the state agency for investment and management of national projects in Ukraine (Kyiv, 2018)

10. Factors of the investment security of the Middleslide (World investment forum, 2018), http://www.itukraine.org.ua/events/svitovyyinvestyciynyy-forum-2-4-kvitnya-2017-dubay-oae. Accessed 10 Mar 2018

11. Order of the Ministry of Regional Development and Construction of Ukraine on Indicators of the indirect cost of housing construction by regions of Ukraine: Pricing in construction. A collection of official documents and explanations 2 (2009), p. 158

12. M. Tregub, Y. Trehub, Substantiation of land management methods of industrial cities Theoretical and Practical Solutions of Mineral Resource Mining, ed. by Pivnyak, Bondarenko, Kovalevs'ka (Taylor \& Francis Group, London, 2015)

13. B. Googin, P. Mirvis, S. Rochlin, Beyond Good Company. Next Generation Corporate Citizenship (Palgrave Macmillan, Boston, 2008)

14. Average price of residential property (2018), https://www.statista.com/statistics/722905/average -residential-square-meter-prices-in-eu-28-percountry/. Accessed 10 Oct 2018

15. A. Caputo, Systemic Stakeholders Management for Real Estate Development Projects (Global Business \& Management Research, 2013), p. 82

16. Real estate analytics (2017), https://www.revolvy.com/main/index.php?s=Studi o\%20flat\&item_type=topic. Accessed 21 Feb 2017
17. Residential Real Estate Analytics (2018) http://xian.com.ua/uk/statistics-and-analytics. Accessed 25 Oct 2018

18. Statistics and dynamics of changes in prices for long-term rental (2018), https://www.citybase.in.ua/statistics/sale_price_ful $1 / \% \mathrm{D} 0 \% \mathrm{~B} 3 \% \mathrm{D} 0 \% \mathrm{BE} \% \mathrm{D} 1 \% 81 \% \mathrm{D} 1 \% 82 \% \mathrm{D} 0 \% \mathrm{~B}$ $8 \% \mathrm{D} 0 \% \mathrm{BD} \% \mathrm{D} 0 \% \mathrm{BA} \% \mathrm{D} 0 \% \mathrm{~B} 0$. Accessed 01 Oct 2018

19. Real estate: sale and rental of real estate (2019), https://www.olx.ua/nedvizhimost/posutochnopochasovo/kha/?utm_medium $=$ cpc\&utm_source= AdWords\&utm_campaign=Nedvizhimost@_Khar kivskaya_Oblast buyers_RLSA_AdWords_Deskt op\&utm_content $=\% \mathrm{D} 0 \% \overline{0} \mathrm{0} \% \mathrm{D} \overline{1} \% 80 \% \mathrm{D} 0 \% \overline{\mathrm{B}} 5 \%$ D0\%BD $\%$ D0\%B4\%D0\%B0 $\%$ D0\%BA $\%$ D0\%BE $\% \mathrm{D} 0 \% \mathrm{BC} \% \mathrm{D} 0 \% \mathrm{BD} \% \mathrm{D} 0 \% \overline{\mathrm{B}} 0 \% \mathrm{D} 1 \% 82 \% \mathrm{D} 0 \% \mathrm{~B}$ E\%D0\%B1\%D1\%8A\%D1\%8F\%D0\%B2\%D0\%B B\%D0\%B5\%D0\%BD\%D0. Accessed 01 Oct 2018

20. S.N. Mehrotra, D.R. Carter, Determinants of Growth in Multiunit Housing Demand since the Great Recession: An Age-Period-Cohort Analysis. Urban Studies Research 2017, 3073282 (2017). doi:10.1155/2017/3073282

21. A. Rezaei, S. Tahsili, Urban Vulnerability Assessment Using AHP. Advances in Civil Engineering 2018, $2018601 \quad$ (2018). doi:10.1155/2018/2018601

22. W. Weidlich, From fast to slow processes in the evolution of urban and regional settlement structures. Discrete Dynamics in Nature and Society 3, 137-147 (1999) doi:10.1155/S1026022699000175

23. A. Masoomeh, H. Fazlollahtabar, A Mathematical Model for Optimizing Organizational Learning Capability. Advances in Operations Research 2014, 490210 (2014). doi:10.1155/2014/490210 